\title{
Urang Banjar: Asal-Usul dan Identitasnya
}

Oleh: Ahmad Harisuddin ${ }^{1}$

\section{A. Pendahuluan}

Pada umumnya, dalam tradisi sosial - bahkan juga dalam konteks akademik, penduduk terbesar Provinsi Kalimantan Selatan yang disebut sebagai masyarakat Banjar sudah sangat lazim dipahami sebagai satu populasi etnik, sehingga kerap disebut 'etnis Banjar' atau 'suku Banjar'. Seseorang yang sejak nenek-datuknya sudah menetap di wilayah Kalimantan Selatan, ketika ditanya orang mana atau apa sukunya, tentu ia akan menjawab sebagai urang Banjar dan bersuku Banjar.

Akan tetapi, semenjak terjadinya berbagai kerusuhan sosial di Indonesia yang konon bernuansa SARA - termasuk yang paling dekat dengan kediaman masyarakat Banjar adalah kasus Sampit di awal milenium ketiga - maka identitas urang Banjar mulai dipertanyakan kembali, bahkan hingga ke asal-usulnya. Secara sosio-kultural, satu contoh menarik yang menggugah munculnya rethinking Banjar ini pernah diungkap oleh Marko Mahin dalam kasus berikut:

"Pada bulan Juni 2004, seorang laki-laki yang bernama Asep datang ke Sungei Kayu, perkampungan orang Dayak Ngaju yang berada di pinggir sungai Kapuas, Kalimantan Tengah. Dengan bahasa Banjar yang kental, ia mengaku dirinya sebagai urang Banjar, tinggal di Banjarmasin tepatnya di belakang Pasar Pandu dan tujuan kedatangannya adalah untuk mencari saudara-saudara kandung almarhum ayahnya. Singkang, penduduk asli Sungei Kayu, orang pertama tempat Asep bertanya, bingung dengan adanya "orang asing" itu. Padahal salah satu nama yang disebutkan Asep sebagai saudara kandung almarhum ayahnya adalah ibu kandungnya sendiri. Karena baginya sebagai orang Dayak sangatlah aneh dan tidak mungkin kalau ia bisa mempunyai saudara sepupu sekali urang Banjar, sedangkan tidak satupun saudara kandung ayah atau ibunya pernah menikah dengan urang Banjar. Setelah melalui perkenalan kekeluargaan, dapat diketahui memang almarhum ayahnya Asep adalah orang Dayak asli kelahiran Sungei Kayu, sedangkan ibunya orang Bugis. Namun ketika ditanya bagaimana caranya bisa menjadi urang Banjar, Asep hanya tertawa dengan wajah bingung. Begitu juga dengan saudara-saudara Dayaknya, yang sebagian sudah memeluk agama Islam."2

Dari kasus di atas, tergambar jelas bahwa Asep tidak menjadi urang Banjar karena faktor geneologis yang lazim menjadi konstruksi identitas utama suatu etnik, sebab ayahnya adalah orang Ngaju dan ibunya orang Bugis. Menurut

\footnotetext{
${ }^{1}$ Penulis adalah Mahasiswa S3 UIN Antasari Banjarmasin; juga menjadi tenaga edukatif pada Sekolah Tinggi Agama Islam (STAI) Darul Ulum Kandangan Kalimantan Selatan.

${ }^{2}$ Marko Mahin, "Urang Banjar: Identitas dan Etnisitas di Kalimantan Selatan”, dalam Jurnal Kebudayaan Kandil, Edisi 6, Tahun II, Agustus-Oktober 2004, h. 4.
} 
pendekatan primordialisme ${ }^{3}$ yang relatif lama mendominasi kajian etnisitas, tentunya Asep menjadi Banjar adalah sudah dari 'sana'-nya (given) karena disetting oleh satu, beberapa, atau akumulasi faktor-faktor berikut: (1) agama, (2) bahasa, (3) wilayah, (4) tradisi budaya, dan (5) organisasi sosial. Menurut Max Weber, pendekatan ini melihat etnisitas sebagai identitas primordial suatu kelompok dan menjadi kategori a priori yang menentukan batasan kelompok guna menjamin stabilitas dan tatanannya. Mereka yang bukan anggota akan dieksklusi berdasarkan fakta bahwa mereka tidak berbagi identitas primordial yang sama; sedangkan para anggotanya tidak pernah bisa menolak identitas etnik primordial tersebut, tanpa mempedulikan faktor-faktor kontekstual atau historis.. Jadi, etnisitas dilandasi oleh sebuah masyarakat organik dan alamiah yang cerminannya adalah kekuatan emosional-etnosentrik, seperti dengan keyakinan bahwa mereka merasa berasal dari nenek moyang yang sama. Oleh karena itulah pendekatan ini banyak dikritik, di mana akan ada orang yang menjadi etnis tertentu bukan karena pilihan dirinya sendiri (askriptis); dan ini tampaknya telah terwakili oleh kasus Asep di atas.

Beranjak dari kasus semacam itu pula, tulisan ini mencoba menganalisis beberapa pendapat yang pernah dikemukakan oleh para pakar sejarah dan budaya tentang asal-usul masyarakat dan identitas Banjar. Selanjutnya, pembahasan akan diarahkan kepada hal-hal yang tampaknya kurang mendapatkan ruang dalam beberapa proses teoritisasi tersebut, untuk selanjutnya dijadikan komplementer bagi terbentuknya sosok kebudayaan Banjar yang beridentitas kokoh di tengah cengkeraman megaproyek globalisasi.

\section{B. Konstruksi Identitas Banjar}

Pembicaraan asal-usul urang Banjar tentunya tidak bisa dipisahkan dari pembahasan tentang berbagai pendekatan dalam kajian etnisitas yang berimplikasi pada konstruksi identitasnya. Sebab, terbentuknya masyarakat Banjar beserta tatanan sosial budayanya merupakan proses yang kompleks dan multi aspek, sehingga untuk mencapai output pencandraan yang lebih integral dan komprehensif, ia tidak bisa dipahami dan dijelaskan secara reduksionis belaka dengan mengambil dan mempertahankan satu pendekatan tanpa dibarengi atau diperkaya dengan pendekatan-pendekatan lain.

Sampai saat ini, tampaknya para pakar sejarah masih belum menemukan kata sepakat tentang asal-usul dan identitas urang Banjar. Sebab, pendekatan yang digunakan dalam memahami dan menganalisis geneologi Banjar tampaknya masih berjalan sendiri-sendiri. Seperti lazim dikenal dalam disiplin sosiologi dan

\footnotetext{
${ }^{3}$ Ulasan Irfan Noor tentang beberapa pendekatan dalam kajian etnisitas Banjar dari hasil diskusi kerjasama LK-3 dengan tabloid Serambi Ummah tanggal 24 September 2004 di Banjarmasin dengan tema "Agama dan Etnisitas (Kajian tentang Asal-Usul Pembentukan Etnis Banjar), dalam Jurnal Kebudayaan Kandil, op. cit., h. 73-80.

http://www.stevegaspersz.wordpress.com/2007/12/07/islam_kristen_dalam_diskursus_kebudayaan _dan_etnisitas
} 
antropologi, ada tiga model atau pendekatan untuk memahami etnisitas, yaitu primordialisme, instrumentalisme, dan konstruktivisme.

Jika primordialisme bersifat ekstrim rigid yang menerjemahkan etnisitas sebagai identitas yang kental dan padat, maka sebaliknya instrumentalisme bersifat ekstrim relatif yang melihat etnisitas sebagai identitas yang cair. Bagi kaum instrumentalis, konsep etnisitas sangat bergantung pada kepentingan tertentu manusia dan tanggapan partikular terhadap suatu peristiwa. Arena utamanya adalah bidang politik. Jika kondisi dan kepentingan berubah, maka berubah pula identitas etnis. Oleh karenanya, menurut Fredrik Barth, kelompokkelompok etnis dilihat sebagai bentuk-bentuk historis dan kontekstual yang content-nya bisa berubah; sehingga fokus instrumentalisme bukan lagi pada esensi, tetapi pada batasan (boundaries) kelompok etnis di mana berlangsung transaksi dengan lingkungan sekitarnya. Etnisitas, dengan demikian, menjadi suatu proses interaksi dinamis di mana berbagai identitas dimobilisasi untuk mengejar cita-cita dan kepentingan-kepentingan tertentu, serta nyaris berfungsi sebagai barter barang-barang sosial, politik dan ekonomi. Menurut model ini, seperti kata D.B. MacKay, agama bisa menjadi suatu aspek sistem sosial seperti aspek lain dari sistem sosial suatu kelompok: ekonomi, politik, kekerabatan atau adat yang semuanya bisa dimobilisasi untuk menentukan batas-batas (border) identitas kelompok etnis. ${ }^{5}$ Dengan demikian, dua pendekatan yang disebut pertama adalah saling beroposisi.

Kemudian, konstruktivisme muncul sebagai penengah di antara kedua kutub pendekatan itu, dengan cara mengombinasikan kedua model sebelumnya. ${ }^{6}$ Konstruktivisme menerima adanya aspek-aspek tertentu dari identitas etnis yang terbawa sejak lahir dan secara determinatif membentuk identitas individu anggota kelompok. Namun, ia sekaligus mengakui pula bahwa setiap anggota kelompok secara kontinyu merekonstruksi aspek-aspek tersebut (juga untuk menanggapi yang bukan-anggota) di dalam suatu konteks lingkungan historis. Identitas etnis bukan given secara eksternal tetapi dicitrakan secara kreatif yang berbeda dengan identitas-identitas lain yang juga dicitrakan secara kreatif. Identitas etnis selalu merupakan ide-ide yang berkembang [atau wacana], ketimbang sebagai unit sosial yang dapat teramati secara empiris.

Cuma, menurut Tilley, kaum konstruktivis terpecah menjadi dua kubu. Kubu satu mengasumsikan bahwa "identitas etnis bukanlah konstruksi intelektual yang dapat dipisahkan secara tegas, melainkan terartikulasi dalam jejaring praktik-praktik sosial dan beragam kepercayaan". Kubu kedua mengandaikan bahwa kaum intelektual memainkan peran penting dalam konstruksi identitas etnis sebagai sebentuk "retorika" ketimbang "wacana". 7

\footnotetext{
5 Steve Gespers, "Islam-Kristen dalam Diskursus Kebudayaan dan Etnisitas: Catatan Kecil dari Maluku”, dalam ibid.

${ }^{6}$ Ibid.

${ }^{7}$ Menarik untuk dipertimbangkan di sini satu tulisan Susanto Zuhdi bahwa kendati tampak spesifik dalam konteks nasionalisme, ia membedakan antara pendekatan situasionalis dengan konstruktivis, bahwa meskipun sama-sama memahami nasionalitas sebagai identitas bentukan, namun kaum situasionalis lebih menekankan aspek rasionalitas-situasional sedangkan kaum
} 
Berdasarkan model-model di atas, dapat dipahami bahwa di masa lalu, umumnya pendekatan yang digunakan dalam kajian etnisitas Banjar adalah primordialisme, sehingga kriteria identifikasi atau konstruksi identitas yang digunakan untuk mencandra geneologi Banjar adalah konstruksi genetika, budaya, dan agama. Dari sini, urang Banjar ditempatkan sebagai satu cabang dari akar etnisitas rumpun Melayu, atau paling tidak sebagai generasi baru etnis Melayu di perantauan, yang disebut oleh J.J. Rass dalam Hikayat Banjar sebagai Melayu periferal. ${ }^{8}$ Sebab, menurut pendekatan ini, entitas Banjar secara kultural adalah bentuk lain dari tampilan kebudayaan Islam-Melayu, meskipun banyak aspek yang sudah berasimilasi dengan unsur-unsur kebudayaan lokal Dayak yang dianggap lebih pribumi. Boleh jadi atas alasan itu, konstruksi genetika urang Banjar kemudian memunculkan dugaan kuat bahwa unsur dominan yang membentuk inti masyarakat Banjar adalah para imigran Melayu Sumatera yang datang ke kawasan Kalimantan Selatan dalam beberapa periode sebagaimana dipopulerkan oleh Alfani Daud. ${ }^{9}$

Jika ditelaah secara leksikal, kesimpulan ini memang sesuai dengan salah satu makna dalam kompleksitas makna etnis itu sendiri, yang dalam Britannica Encyclopedia, misalnya, diartikan sebagai a social group or category of the population that, in a larger society, is set apart and bound together by common ties of race, language, nationality, or culture. ${ }^{10}$ Webster Dictionary juga mendefinisikan kata ethnic salah satunya sebagai of or relating to large groups of people classed according to common racial, national, tribal, religious, linguistic, or cultural origin or background. ${ }^{11}$ Di dalam Kamus Besar Bahasa Indonesia sendiri, kata "suku bangsa" didefinisikan sebagai kesatuan sosial yang dapat dibedakan dari kesatuan sosial lain berdasarkan kesadaran akan identitas perbedaan kebudayaan, khususnya bahasa. ${ }^{12}$ Secara lebih luas, dengan demikian dapat dipahami bahwa konsep etnis dapat merujuk pada kesatuan sosial yang terbentuk atas sebuah kesadaran kolektif-kultural, sehingga dianggap berbeda dengan kesatuan sosial lain, baik perbedaan itu terletak dalam hal genetika, adat, agama, bahasa, atau identitas lainnya; dan tidak jarang pada beberapa kasus

konstruktivis menekankan aspek ideologis-institusional. Susanto Zuhdi, "Lawatan Sejarah" dan Integrasi Bangsa", dalam www.kongresbud.budpar.go.id/susanto_zuhdi.htm

${ }^{8}$ J.J. Rass, Hikajat Bandjar: A Study in Malay Historiography, diterjemahkan ke dalam bahasa Melayu oleh Siti Hawa Saleh dengan judul Hikayat Banjar, (Kuala Lumpur: Dewan Bahasa Kementerian Pendidikan, 1991), h. 11-12.

9 Alfani Daud, Islam dan Masyarakat Banjar: Diskripsi dan Analisas Kebudayaan Banjar, (Jakarta: Raja Grafindo Persada, 1997), cet. I, h. 25 dan 31. Pendapat ini ditegaskannya kembali dalam beberapa kesempatan dari diskusi perkuliahan hingga pertemuan-pertemuan ilmiah lainnya, antara lain Alfani Daud, "Islam dan Asal-Usul Masyarakat Banjar", dalam Jurnal Kebudayaan Kandil, op.cit., h. 85. Oleh karena itu, wajar jika dalam konteks kajian Banjar Irfan Noor kemudian menyebutnya sangat primordialistik. Irfan Noor, loc. cit.

${ }^{10} \mathrm{http}: / / \mathrm{www}$. britannica.com/ethnic

${ }^{11} \mathrm{http}: / / \mathrm{www} . \mathrm{merriam}-\mathrm{webster.com/dictionary/ethnic}$

12 Tim Penyusun Kamus, Kamus Besar Bahasa Indonesia, (Jakarta: Balai Pustaka, 1990), cet. III, h. 865. Kata etnik yang bersinonim dengan etnis di sini juga didefinisikan sebagai kata sifat yang bertalian dengan kelompok sosial dalam sistem sosial atau kebudayaan yang mempunyai arti atau kedudukan tertentu karena keturunan, adat, agama, bahasa, dan sebagainya. ibid., h. 237. 
identitas itu saling tumpang tindih satu sama lain menjadi semacam sirkuit budaya.

Belakangan, setelah kajian poskolonial mulai diaplikasikan di Tanah Banjar, konstruksi model lama dalam pendekatan primordialistik tersebut memancing kritikan tajam, karena dianggap sangat bias kolonial. Memang, identifikasi terhadap orang Banjar yang dilakukan oleh pihak Hindia Belanda zaman dulu tidak beranjak jauh dari ketiga konstruksi tersebut: Jika seseorang yang bertempat tinggal di daerah tradisional Banjar menunjukkan ciri-ciri fisik Melayu, ${ }^{13}$ bisa berbahasa Banjar dengan fasih, dan beragama Islam, hampir bisa dipastikan akan diidentifikasi sebagai urang Banjar.

Sungguhpun demikian, uniknya, kerangka konstruktivikasi versi kolonial Belanda itu tampak sedemikian rupa telah diinternalisasi ${ }^{14}$ oleh masyarakat Banjar sendiri baik secara sadar ataupun tidak, sehingga mereka berupaya membedakan antara orang yang lebih maju dengan orang yang tertinggal, orang beradab dengan belum beradab, bahwa kelompok pertama sering diidentifikasi sebagai orang Banjar di mana mereka mengklaim sebagai bagian inherennya dan kelompok kedua sebagai orang Bukit atau orang Dayak. ${ }^{15}$ Jadi, tampak bahwa kesamaankesamaan identitas dikonstruksi oleh masyarakat Banjar secara internal untuk membedakan kolektifitas mereka dari orang-orang pedalaman yang diasosiasikan sebagai Dayak, meskipun tinggal dalam satu kawasan yang sama.

Di sini, kritikan ala poskolonialis terhadap pendekatan primordialisme di atas tampaknya sangat dipengaruhi oleh teoritisasi sejarawan M. Edwar Saleh dalam beberapa bukunya di sekitar pergantian dasawarsa 1970-an dengan 1980-an. Menurut M. Edwar Saleh, masyarakat Banjar bukanlah sebuah etnis sejak pembentukannya, dan ia tidak muncul sebelum berdirinya Kerajaan Banjar (Kesultanan Banjarmasin) pada abad XV M. Bahkan, sebagai masyarakat pun pembentukan entitas Banjar an sich tampak lebih terlambat, karena di abad XV M itu yang eksis secara sosio-kultural dan kemudian membentuk struktur masyarakat yang tunduk kepada Kerajaan Banjar hanyalah tiga grup atau kelompok besar yang masing-masing biasa disebut sebagai (1) kelompok Banjar Kuala yang berasal dari kesatuan-etnik Ngaju, (2) kelompok Banjar Batang Banyu yang berasal dari kesatuan-etnik Maanyan, dan (3) kelompok Banjar Pahuluan yang berasal dari kesatuan-etnik Bukit. ${ }^{16}$ Artinya, berbagai kesatuan-etnik yang

\footnotetext{
${ }^{13}$ Pada konteks ini, ada perbedaan persepsi dalam memaknai konsep Melayu sebagai asal-usul urang Banjar, yaitu antara Melayu sebagai rumpun etnis yang sekarang berbasis di pulau Sumatera dan semenanjung Malaya seperti diwakili oleh pendapat Alfani Daud dengan Melayu sebagai ras (Malayan Mongoloid) sebagaimana dipegang oleh Tajuddin Noor Ganie, yang keduanya akan dibahas kemudian.

14 Di sini masih perlu didiskusikan apakah memang persepsi masyarakat Banjar tentang dirinya sendiri yang relatif identik dengan Melayu dan Islam dikonstruksi oleh warisan oposisi binner Kolonial atau bukan.

${ }^{15}$ M. Edwar Saleh, Sekilas Mengenai Daerah Banjar dan Kebudayaan Sungainya Sampai dengan Akhir Abad-19, (Banjarbaru: Museum Negeri Lambung Mangkurat, 1983/1984), h. 11. Lihat juga Abdurrahman, Beberapa Catatan tentang Undang-Undang Sultan Adam Ditinjau dari Persfektif Sejarah Hukum, Hukum Islam, dan Hukum Adat Banjar, (Banjarmasin: Fakultas Hukum UNLAM, 1984), h. 14.

${ }^{16}$ M. Edwar Saleh, Sekilas..., op. cit., h. 11.
} 
menjadi inti masyarakat Banjar tidaklah lain dari suku-suku bangsa pribumi ${ }^{17}$ Kalimantan yang belakangan masuk ke dalam rumpun-etnik Dayak.

Dari sini terlihat bahwa Marko Mahin dan koleganya berusaha menegaskan kembali pernyataan Edwar Saleh pada lebih kurang dua dasawarsa silam. Secara substansial, baik Edwar Saleh maupun Mahin dan tokoh-tokoh yang sepaham dengan mereka tampak merefleksikan pendekatan konstruktivis atau situasionalis yang menekankan bahwa suatu organisasi sosial dari perbedaan-perbedaan etnis adalah hasil dari interaksi dengan kelompok sosial lainnya. Jadi, masyarakat Banjar bukanlah sesuatu yang hadir begitu saja, tetapi ia merupakan konstruksi historis secara sosial oleh suatu kelompok manusia yang menginginkan suatu komunitas tersendiri yang berbeda dari komunitas-komunitas lain yang ada di pulau Kalimantan ini. ${ }^{18}$

Oleh karena itu, perbedaannya mungkin lebih dalam perspektif saja, di mana Mahin dan kawan-kawan tampak lebih menonjolkan perspektif poskolonialnya dalam mengemukakan kembali pendapat itu, sehingga status quo kajian mengenai Banjar yang berada dalam sinar terang adagium "Banjar adalah Islam dan Islam adalah Banjar" harus didobrak dan dilakukan perubahan paradigmatik sedemikian rupa dengan menempatkan entitas Banjar sebagai apa yang diistilahkan oleh St. Sunardi dengan "poros dunia"19 tempat kajian tersebut harus bertolak.

Penulis sepakat bahwa untuk mengkaji Banjar pertama-tama harus dimulai dengan menetralkan karakter status quo itu, yaitu dengan meneliti teks-teks yang dibuat oleh urang Banjar sendiri sebelum mereka bertemu dengan teks-teks Barat yang sarat dengan ide-ide kolonial dari para indolog dan orientalis. ${ }^{20}$ Jika meminjam bahasa Sunardi, ini adalah kesempatan setiap wilayah atau kelompok untuk menjadi pusat dalam konstetasi tawar-menawar dengan proyek besar globalisasi. ${ }^{21}$ Namun demikian, yang juga tidak kurang pentingnya adalah kesadaran bahwa sebelum zaman kesarjanaan sekarang, seperti diungkap Fritz Meier, karya-karya sastra warisan generasi lampau tampak lebih banyak dibaca sebagai sarana penghibur daripada sebagai sejarah, sehingga tidaklah begitu penting untuk menghubungkan antar sumber sejarah, mempertanyakan dari mana si penulis mengambil data, dan ke dalam mata rantai perkembangan mana penulis bersangkutan masuk. ${ }^{22}$ Artinya, karya-karya "orisinil" itu pun tidak lantas absah sebagai referensi otoritatif.

17 Konsep pribumi pun masih layak diperdebatkan, namun dalam konteks ini yang dimaksudkan adalah suku yang meskipun dahulu kala berimigrasi dari tempat lain, secara turun temurun tinggal di wilayah tertentu dan merasa sebagai tanah airnya. Lihat Edi Sedyawati, Budaya Indonesia Kajian Arkeologi, Seni, dan Sejarah, (Jakarta: Raja Grafindo Persada, 2001), h. 315.

18 Irfan Noor, "Islam dan Universum Simbolik Urang Banjar", dalam Jurnal Kebudayaan Kandil, op.cit., h. 60.

${ }^{19}$ St. Sunardi, "Islam Liberal dan Krisis Liberalisme", dalam Jurnal Gerbang, Nomor 13, Vol. V, Oktober 2002-Januari 2003, h. 74.

${ }^{20}$ Marko Mahin, op. cit., h. 23.

${ }^{21}$ St. Sunardi, loc. cit.

${ }^{22}$ Fritz Meier, "Metode-Metode Pendekatan", dalam Gustave E. von Grunebaum (ed.), Unity and Variety in Muslim Civilization, diterjemahkan ke dalam bahasa Indonesia oleh Effendi N. Yahya dengan judul, Islam: Kesatuan dalam Keragaman, (Jakarta: Yayasan Obor, 1975), cet. II, h. 41 . 
Hal ini berkonsekuensi bahwa informasi-informasi yang dimuat oleh sumbersumber pseudo-historis lokal semacam "Tutur Candi", "Hikayat Banjar", dan "Ceritera Lambung Mangkurat" harus dikonfrontasikan juga dengan sejumlah sumber lainnya. Sebagai contoh, karena karakternya yang masih tergolong 'sejarah politik' lantaran berkutat pada sejarah raja-raja, timbul-tenggelamnya para penguasa, naik-turunnya berbagai dinasti, atau bangun-runtuhnya rezimrezim politik, tentulah bahwa sumber-sumber tersebut harus dipararelkan dengan sumber-sumber 'sejarah sosial' 23 yang dapat menggambarkan keadaan rakyat dengan berbagai proses transformasinya secara lebih analitis, atau paling tidak potensial dan terbuka untuk itu.

Dengan demikian, terlepas dari motivasi apapun yang mengiringinya, konstruksi model lama tetap harus dihargai, karena setidaknya ia memberikan kerangka dasar yang cukup prospektif bagi pengembangan identifikasi lebih lanjut. Dalam hal ini, rujukan kepada Melayu dalam konstruksi lama menempatkan nenek moyang etnis Banjar sebagai pendatang atau imigran, yang dalam budaya Melayu sendiri dikenal dengan sebutan rantau. Jadi, dalam konstruksi ini tergambar bahwa etnis Banjar sesungguhnya adalah salah satu subetnis belaka dari rumpun besar etnis Melayu. Orang Banjar secara umum, jika mengikuti konstruksi ini, memang tidak dapat mengurut silsilah (bahasa Banjar: cuur) dan menunjukkan daerah asal mereka di Tanah Melayu, baik di pulau Sumatera maupun di Tanah Semenanjung; suatu fenomena yang berbeda, misalnya, dari tradisi Ulakan yang juga satu sub-etnis Melayu di Sumatera, bahwa orang yang tidak dapat menunjukkan daerah darek asal nenek moyangnya di Tanah Minangkabau berarti bukan asli orang Ulakan. ${ }^{24}$ Fakta yang berlangsung dalam konteks Banjar, menurut Tajuddin Noor Ganie, justru sebaliknya, bahwa sebagian orang yang berdiam di Tanah Melayu mengakui banua Banjar sebagai asal-usul nenek moyang mereka. ${ }^{25}$

Sebelum menganalisis, paling tidak ada dua hal yang mesti diklarifikasi lebih dahulu di sini. Sebab, sepanjang hemat penulis, tanpa ada kejelasan dan ketegasan dalam kedua hal ini, kajian tentang asal-usul dan identitas Banjar akan semakin sulit menemukan sosok Banjar yang sesungguhnya dalam pertarungan identitas etnik. Kedua hal tersebut adalah persoalan kriteria Melayu dan problem identifikasi internal yang terdapat dalam masyarakat Banjar itu sendiri.

Pertama, masalah kriteria Melayu, di mana tampaknya para pakar masih belum menemukan titik tolak yang bisa disepakati dalam memahami konsep Melayu. Sebagai contoh, pada ranah wilayah ada satu kutub pendapat yang tampak bertolak dari konsep Melayu sebagai nama etnik yang sekarang merupakan masyarakat dominan di Pulau Sumatera dan Semenanjung Malaya, dan kutub pendapat lain justru bertolak dari konsep kultural yang berasaskan

${ }^{23}$ Di bidang sejarah sosial ini, Indonesia dikatakan relatif bagus dan kaya dengan karya-karya bermutu. M. Dawam Rahardjo, "Ilmu Sejarah Profetik dan Analisis Transformasi Masyarakat", Pengantar dalam Kuntowijoyo, Paradigma Islam, (Bandung: Mizan, ), h. 11-13.

${ }^{24}$ Duski Samad, Syekh Burhanuddin dan Islamisasi Minangkabau, (Jakarta: The Minangkabau Foundation, 2003), Cet. 2, h. 65.

${ }^{25}$ Tajuddin Noor Ganie, op. cit., h. 25-27. 
peranan bahasa Melayu dalam batas geografi Asia Tenggara yang biasa disebut "alam Melayu". Pada ranah lain, ditemukan pula pola-pola hubungan yang rumit antara konsep Melayu Tua (proto-Melayu) yang kerap dilekatkan pada etnik-etnik yang sekarang mayoritas mendiami kawasan pedalaman pulau, seperti etnik Batak di Sumatera, rumpun etnik Dayak di Kalimantan, dan etnik Toraja di Sulawesi, dengan konsep Melayu Muda (deutro-Melayu) yang diidentifikasi kepada etniketnik pesisir yang termasuk dalam rumpun etnik Melayu, termasuk etnik Bugis dan Mandar di Sulawesi serta etnik Kutai dan Banjar di Kalimantan. Bagaimanapun, masalah ini cukup kompleks dan belum kunjung terpecahkan.

Kedua, masalah identifikasi internal dalam suatu kelompok masyarakat. Perasaan sebagai orang Melayu yang muncul dalam diri seseorang yang mengaku urang Banjar adalah kenyataan yang tidak bisa dibantah, terlepas dari ke aspek Melayu yang bagaimana ia melayangkan identifikasi dirinya itu. Begitu pula pada sisi lain, terdapat kesulitan dalam menjelaskan hubungan kekerabatan "dingsanak" antara urang Banjar dengan urang Bukit yang secara primordial akrab namun cenderung mencair ketika proses-proses sosial "memaksa" urang Banjar lebih mengidentifikasikan dirinya sebagai Melayu sehingga kemudian menjadi MelayuBanjar, sementara urang Bukit mengidentifikasikan dirinya sebagai Dayak yang kemudian menjadi Dayak-Meratus.

Untuk menguraikan kedua masalah yang kompleks di atas, pembahasan berikut setidaknya akan memberikan ruang ke arah kesepahaman dan titik temu dari berbagai silang pendapat yang ada. Secara kronologis, pembahasan diturunkan dengan meminjam faktor-faktor yang dijadikan oleh pendekatan primordialisme sebagai determinator alamiah suatu identitas etnik, antara lain wilayah, bahasa, agama, tradisi budaya, dan organisasi sosial. Secara inheren, faktor-faktor tersebut akan didialogkan dengan pendekatan instrumentalis dan konstruktivis.

1. Wilayah

Dalam konteks Melayu, ada semacam pendapat umum di kalangan sejarawan tentang migrasi kolosal etnis ini ke pulau Kalimantan yang kemudian melahirkan etnis Banjar. Alfani Daud, misalnya, menyatakan bahwa etnis Banjar berasal dari migrasi besar-besaran kelompok Melayu Sumatera pada zaman Sriwijaya (abad ke-7 M, pen.), atau bahkan sejak masa sebelumnya; di mana migrasi tersebut terjadi tidak hanya dalam satu gelombang. ${ }^{26}$

Dengan kisaran zaman yang lebih dini, Idwar Saleh dan Abdurrahman masing-masing menyatakan bahwa migrasi besar ini kemungkinannya terjadi pada abad I Masehi, sesuai dengan pendapat J.J. Rass. Para imigran itu memasuki bagian timur teluk raksasa pulau Kalimantan, di mana kaki pegunungan Meratus sebagai pantainya, yang kemudian dikenal dengan sebutan Banua Ampat pada wilayah Selatan dan Banua Lima di wilayah Utara. Di kedua wilayah tua ini-lah golongan imigran Melayu tersebut hidup berbaur dengan beberapa kelompok Maanyan dan Bukit yang kala itu sudah bisa disebut sebagai penduduk pribumi, yang kemudian me-lahirkan inti pertama etnis Banjar (proto-Banjar).

${ }^{26}$ Alfani Daud, op. cit., h. 25 dan 31. 
Proses kelahiran ini secara sosio-politik ditandai dengan berdirinya Kerajaan Nan Sarunai, Kuripan, atau disebut juga Tanjung Pura, yang menjadikan Budha sebagai agama resmi kerajaan, dan beribukota Kahuripan atau Tanjung Puri. Keraton Tanjung Pura ini sangat mungkin terletak di dekat kota Tanjung, ibukota Kabupaten Tabalong sekarang, ${ }^{27}$ dan ada pula yang menduganya di Palimbang Sari, dekat kota Amuntai dan sekarang bernama kampung Palimbangan. ${ }^{28}$

Keberadaan Kerajaan Tanjung Pura ini diperkuat dengan merujuk sejarah Majapahit, bahwa gerakan yang dikenal dengan mitrekasatata di pertengahan abad ke-14 M dan dipimpin oleh Patih Gajah Mada telah berhasil menghimpun sebagian besar wilayah Nusantara ke dalam kekuasaan Majapahit, termasuk wilayah yang disebut Tanjung Pura, meskipun tentunya tinggal menjadi nama daerah lantaran Kerajaannya sendiri sudah tiada, digantikan oleh Kerajaan Negara Dipa. $^{29}$

Sungguhpun demikian, Tajuddin Noor Ganie meragukan pendapat ini, karena menurutnya tidak terdapat bukti historis yang menunjukkan dominasi politik koloni Melayu di Tanah Banjar, kecuali apa yang disebut-sebut sebagai Kerajaan Nan Sarunai tersebut. Selebihnya, dinasti kerajaan lain justru dibangun dan diperintah oleh orang-orang Jawa. Di samping itu, ia memandang bahwa mata rantai kemelayuan dalam genetika orang Banjar boleh dikatakan terputus, karena mereka tidak bisa menunjuk daerah Melayu mana yang menjadi asal-usul nenek moyang mereka di zaman dahulu.

Kemudian pada sisi lain ia juga menyatakan bahwa peristiwa migrasi besarbesaran kelompok Melayu dari Pulau Sumatera dan Tanah Semenanjung Malaya ke kepulauan Nusantara lainnya, yang barangkali termasuk ke pulau Kalimantan, sebenarnya terjadi dalam dua gelombang pada masa yang jauh lebih muda (atau setidaknya hal inilah yang dapat ditemukan referensinya dalam khazanah sejarah Melayu-Indonesia, Pen.): Gelombang pertama, terjadi ketika selat Malaka diserang oleh armada perang dari Cola Mandala tahun 1025-1026 M, dan gelombang kedua terjadi ketika Melaka berhasil diduduki Portugis pada tahun $1511 \mathrm{M}$.

Akhirnya, Tajuddin berpendapat bahwa etnis Banjar harus diakui sebagai penduduk asli Kalimantan, sama halnya rumpun etnis Dayak yang juga merupakan bagian dari ras Malayan-Mongoloid. Bahkan antara Banjar dengan Dayak terdapat hubungan genetik yang sangat erat, kecuali bahwa identitas genetik itu dibedakan oleh kenyataan ekspresi sosio kultural mereka masing-

${ }^{27}$ Abdurrahman, op. cit., h. 13-14. Bandingkan dengan M. Idwar Saleh, Sejarah Daerah Kalimantan Selatan, (Jakarta: Proyek Inventarisasi dan Dokumentasi Kebudayaan Daerah, 1978), Cet. 1, h. 16-17. Lihat pula Humaidy, "Tradisi Demokrasi dalam Budaya Banjar" dalam Buletin Wacana Postra, Edisi 06 2002, h. 53-54.

${ }^{28}$ Anggraini Antemas, op. cit., h. 14. Lihat pula hubungannya dengan penggunaan nama Tanjung Pura di Kalimantan Barat yang memiliki kesamaan konteks dalam ibid., h. 40.

${ }^{29}$ Lihat Marwati Djoened Poesponegoro dan Nugroho Notosusanto, Sejarah Nasional Indonesia II, (Jakarta: Balai Pustaka, 1993), Edisi 4, Cet. 8, h. 434. Bandingkan dengan Anggraini Antemas, op. cit., h. 16-17. 
masing yang terbentuk secara khas; di mana bagi masyarakat Banjar ekspresi itu ditonjolkan oleh bahasa Banjar, budaya sungai, dan agama Islam. ${ }^{30}$

2. Bahasa

Menurut sebagian peneliti, kemungkinan etnis Melayu sebagai asal-usul etnis Banjar terindikasi lewat kesamaan pola bahasa yang dikembangkan oleh kedua etnis, sehingga bahasa Banjar dianggap sebagai satu dialek belaka dari rumpun bahasa Melayu. ${ }^{31}$ Hal ini pararel dengan etnis Bukit yang sampai sekarang bersama-sama etnis Banjar mendiami wilayah Kalimantan Selatan, bahwa bahasa yang mereka kembangkan juga dapat dikatakan sebagai bahasa Banjar kuno (arkais). Jadi, kedua etnis ini boleh dikatakan sebagai bagian integral dari komunitas linguistik Melayu.

Di samping itu, ragam bahasa tulisan yang digunakan oleh masyarakat Banjar bahkan tidaklah berbeda dari bahasa resmi Melayu yang disebut pula sebagai bahasa persuratan. Seperti terlihat dalam kesusastraan Islam Nusantara, yakni kitab-kitab kuning, yang secara kultural masih eksis hingga sekarang, bahasa resmi ini ditulis dengan menggunakan pola huruf Arab tanpa baris (harkah) beserta beberapa tambahan huruf dan ejaan yang khas Melayu dan tidak terdapat dalam tradisi penulisan bangsa Arab, seperti huruf yang berfonem "c", "ny", dan "ng".

Ragam tulisan bahasa Melayu resmi dipergunakan oleh masyarakat Banjar dalam hal kesusastraan, surat-menyurat, dan publikasi-publikasi umum, terlepas dari kuat atau lemah penguasaan mereka dalam hal tersebut. Namun demikian, bahasa resmi ini tetap menjadi standar kecakapan baca-tulis mereka, terutama sebelum zaman kemerdekaan Indonesia, dalam artian bahwa derajat kecakapan baca-tulis penduduk Banjar sangat ditentukan oleh sejauh mana tingkat "kemurnian" seseorang di dalam menggunakan bahasa persuratan Melayunya. ${ }^{32}$

Jika merujuk temuan arkeologis di tahun $1958 \mathrm{M}$ berupa kapak perimbas di dasar sungai Riam Kanan Kabupaten Banjar yang mewakili daerah Banjar Kuala, dan fosil manusia purba ras Austro-Melanesia yang ditemukan pada tahun $2006 \mathrm{M}$ di Gua Batu Babi Kabupaten Tabalong daerah ujung Utara Banjar Hulu seperti disebut Tajuddin, tentu dapatlah disimpulkan bahwa kawasan ini memang sudah dihuni oleh manusia purba berjenis pithecantropus sejak zaman paleoletikum (batu tua) sekitar 8-13 ribu tahun yang lampau, ${ }^{33}$ atau kurang lebih 6-11 abad sebelum perhitungan Masehi.

Masalahnya tidak lain dari minimnya peninggalan sejarah arkeologis lain yang lebih dapat menguak masa lampau Kalimantan kecuali apa yang disebut yupa atau prasasti Kutai yang merujuk abad ke-5 Masehi itu, serta beberapa makam tua dan pecahan keramik purba di daerah Kutai Timur yang diduga hasil budaya sebelum berkuasanya Raja Mulawarman. ${ }^{34}$ Oleh karenanya, dapatlah dipahami bahwa

\footnotetext{
${ }^{30}$ Tajuddin Noor Ganie, op. cit., h. 2 dan 25-28.

${ }^{31}$ Alfani Daud., loc. cit.

${ }^{32}$ J.J. Rass, op. cit., h. 10.

${ }^{33}$ Ibid., h. 9-10.

${ }^{34}$ Anggraini Antemas, op. cit., h. 8.
} 
pulau besar ini baru teridentifikasi oleh sejarah sejak mulai tertanamnya pengaruh kebudayaan India di kepulauan Nusantara, yang antara lain diwakili oleh keberadaan peninggalan sejarah Raja Mulawarman tersebut.

Dengan demikian, bukan mustahil bahwa jauh sebelum berdirinya kerajaan Kutai purba, sudah terdapat konsentrasi-konsentrasi kekuasaan politik di Kalimantan, yang berarti pula telah berkembangnya kebudayaan-kebudayaan lokal. Hanya saja, institusi yang berbentuk kerajaan belum dikenal oleh penduduk pribumi, karena ia merupakan produk budaya internasional yang mengenal stratifikasi ketat dalam struktur sosio-politik masyarakatnya, seperti ditunjukkan oleh sangat kuatnya pengaruh India dalam penubuhan dinasti Kutai itu.

Munculnya nama Kundunga dalam yupa (prasasti) Kutai yang teridentifikasi sebagai nama Indonesia asli, memperkuat kemungkinan itu, sehingga ia bukanlah dikenal sebagai nenek moyang pendiri dinasti Kutai, melainkan sebagai tapal batas sejarah yang membedakan antara Kutai purba yang khas Indonesia dengan Kutai baru yang mengadopsi corak kebudayaan India. ${ }^{35}$ Hal ini diperkuat oleh kenyataan bahwa pada sebagian etnis Dayak, Kundunga itu disebut dengan Datu Kundung, yang mengingatkan kita pada tradisi penyebutan orang-orang besar dalam tradisi Melayu. ${ }^{36}$

\section{Agama dan Tradisi Budays}

Pada sisi lain, juga ditemukan korelasi geneologis bangsa Melayu tua (protoMelayu/ras Malayan Mongoloid) dengan Melayu muda (deutro-Melayu) dalam konteks terbentuknya entitas Banjar baik sebagai etnis maupun sebagai budaya lokal di Kalimantan. Proto-Melayu yang daerah asalnya sering dirujuk kepada daerah Yunan di Cina Selatan, memang memiliki kesamaan identitas dengan rumpun etnis Dayak, sehingga boleh jadi yang disebut terakhir memiliki akar genetik yang sama dengan kelompok-kelompok proto-Melayu Sumatera. Para imigran Yunan ini, selain menetap di Sumatera, juga sudah menetap di Kalimantan sejak zaman Paleolitik, ${ }^{37}$ sehingga karenanya menjadi penduduk pribumi Kalimantan. Arthum Artha menjelaskan bahwa penggunaan istilah balai dan tradisi memotong kepala (mengayau) yang sering ditemukan pada kebanyakan etnis Dayak juga dapat ditemukan di daerah pegunungan Assam. Begitu pula adat lapis gigi dapat dirujuk geneologinya dari provinsi Yunan. ${ }^{38}$ Bahkan, Anggraini Antemas juga menghubungkan raut muka dan warna kulit orang Dayak dengan orang Cina. ${ }^{39}$

Selanjutnya, jika etnis Banjar diidentifikasi berasal dari rumpun etnis Dayak, hal ini harus dipahami dalam kerangka di atas bahwa secara geneologis rumpun etnis Dayak sendiri merupakan bagian dari sisa-sisa rumpun proto-Melayu asal imigran Yunan yang - sesuai faktor ekologis pedalaman - masih kuat memegang religi dan adat leluhur mereka sampai masuknya agama Hindu, Budha, dan Islam

\footnotetext{
${ }^{35}$ Marwati Djoened Poesponegoro dan Nugroho Notosusanto, op. cit., h. 31.

${ }^{36}$ Anggraini Antemas, op. cit., h. 9.

${ }^{37}$ Tajuddin Noor Ganie, loc. cit.

${ }^{38}$ Lihat Arthum Artha, Dari Bandarmasih ke Banjarmasin, (Banjar-masin: Pustaka Artha Mardaheka, h. 101-102.

${ }^{39}$ Anggraini Antemas, op. cit., h. 11.
} 
ke perairan Nusantara; sedikit berbeda dengan proto-Melayu Sumatera yang lebih mobil dan dinamis, terutama karena domisili mereka yang tampaknya lebih menyukai daerah-daerah pesisir.

Dari sini, penulis cenderung kepada kesimpulan bahwa sejarah pembentukan etnis Banjar berada dalam latar belakang genetik rumpun etnis Dayak yang telah mengalami proses hibridasi (persilangan) budaya dengan unsur-unsur kebudayaan luar dalam interval masa yang cukup panjang, yang dilihat dari peninggalan arkeologis dan folklor secara umum, tampak lebih banyak dipengaruhi oleh kebudayaan Melayu (baik proto-Melayu Sumatera-Semenanjung maupun deutroMelayunya), kemudian oleh tradisi agama Islam, dan terakhir oleh tradisi religiopolitik Jawa lewat penubuhan dinasti-dinasti sejak Kerajaan Negara Dipa sampai dengan Kesultanan Banjarmasin.

Oleh karena itu, etnis Melayu, yang diidentifikasi sebagai unsur dominan pembentuk etnis Banjar, memang bisa saja merujuk kepada etnis Melayu yang sekarang berpusat di Sumatera dan Tanah Semenanjung Malaya. Ada beberapa alasan penting yang mendukung pendapat ini: pertama, di masa lalu, apa yang sekarang disebut paham nasionalisme belum terbentuk di kawasan nusantara ini. Bahkan, di Eropa pun konsep ini baru diperkenalkan pada akhir abad ke-18 M. Oleh karena itu, tidak mengherankan bahwa di zaman dahulu orang Bugis bisa menaiki tahta Johor, yang nota bene merupakan kerajaan bentukan etnis Melayu; dan Broke yang asli orang Inggris bisa menjadi raja Serawak. Bahkan, orangorang Cina sampai tahun 1850-an M masih hidup rukun berdampingan dengan kelompok-kelompok Dayak di daerah pedalaman Kalimantan. ${ }^{40}$

Kedua, dilihat dari sejarah Melayu sendiri, menurut J. J. de Hollander, migrasi besar-besaran (tampaknya sebagai gelombang imigran deutro-Melayu, pen.), terjadi di tahun $1160 \mathrm{M}$, di mana etnis Melayu yang saat itu berkonsentrasi di sekitar Palembang dan Jambi, bergerak menyisiri pantai Timur Sumatera dan seterusnya menyeberang ke kepulauan Riau. Sebagian menetap di sana dan sebagian lagi melanjutkan perantauan sampai ke Tanah Semenanjung (Malaya, pen.). ${ }^{41}$

Meskipun informasi di atas tidak menyebutkan motivasi dari migrasi dan daerah perantauan lain di luar kepulauan Riau dan Tanah Semenanjung, namun dapat diduga bahwa sebagian imigran Melayu juga sampai ke Tanjung Pura. Hal ini diperkuat oleh penuturan Hikayat Banjar bahwa di zaman pembentukan kerajaan Negara Dipa oleh Empu Jatmika, sudah diduga adanya orang-orang Melayu yang menetap di wilayah proto Banjar, di mana mereka turut diperintahkan untuk menanggalkan adat asli mereka dan menggantinya dengan

\footnotetext{
${ }^{40}$ Ong Hok Ham, "Masalah Cina di Indonesia Ditinjau dari Sejarah Indonesia" dalam Yahya Theo (ed.), Sekitar Pembauran Bangsa di Indo-nesia, (Jakarta: Yayasan Kesejahteraan Keluarga Pemuda "66", 1985). Cet. 1, h. 6 dan 9.

${ }^{41}$ J. J. de Hollander, Handlelding bij de beofening der Maleische Taalen, diterjemahkan oleh T. W. Kamil dengan judul Pedoman Bahasa dan Sastra Melayu, (Jakarta: Balai Pustaka, 1984), Cet. 1, h. 221-223.
} 
adat-istiadat Majapahit. Menurut Anggraini Antemas, peristiwa ini terjadi sekitar tahun 1250-an M. ${ }^{42}$

Dari sini, kita juga bisa menerima keempat versi tentang sejarah migrasi etnis Melayu yang melahirkan masyarakat dan kebudayaan Banjar di atas. Artinya, keseluruhan periode itu menjelaskan bagaimana proses pembanjaran berlangsung sedemikian lama, dan terdapat banyak faktor yang berperan di dalamnya. Sinkronisasi tersebut dapat dijelaskan sebagai berikut:

- Kisaran zaman prasejarah yang menunjukkan keberadaan penduduk dan kebudayaan arkais di bagian tenggara pulau Kalimantan secara umum belum bisa digunakan untuk menjelaskan keberadaan etnis dan kebudayaan Banjar, lantaran artefak dan fosil yang ditemukan adalah bukti-bukti umum yang dimiliki oleh seluruh kebudayaan di dunia, tidak berciri lokal;

- Pada abad ke-1 M, kelompok proto-Melayu diduga sudah melakukan migrasi ke pulau Kalimantan dan mulai menjalani proses pribumisasi (menjadi pribumi), yang kemudian pada umumnya sering disebut sebagai orang Dayak untuk daerah pedalaman pegunungan dan orang Melayu untuk daerah lembah sungai dan pesisir pantai. Banjar ditengarai jadi bagian dari Melayu;

- Pada abad ke-7 M, kerajaan Sriwijaya membentuk koloni, atau jika tidak, mungkin pula menaklukkan penguasa Kalimantan bagian Selatan kala itu yang disebut Kerajaan Tanjung Pura, dan di masa ini terjadi migrasi gelombang kedua etnis deutro-Melayu, yang salah satunya adalah ke daerah Tanjung Pura tersebut, sehingga mendorong terbentuknya kebudayaan proto-Banjar yang lebih khas akibat perpaduan genetik dan kultural (polapola budaya) dengan penduduk pribumi;

- Pada abad ke-11 dan $12 \mathrm{M}$ terjadi lagi migrasi kelom-pok Melayu ke Tanjung pura, yang beriringan dengan terbentuknya etnis Melayu di Tanah Semenanjung. Kelompok Melayu yang datang lebih belakangan ini-lah yang mungkin disebut orang Melayu pada masa-masa belakangan, seperti terbukti dengan adanya Kampung Melayu di Banjarmasin dan Martapura, namun keberadaan mereka sudah tidak bisa dibedakan lagi dengan penduduk asal daerah lain yang terlibat dalam proses melting pot pembanjaran.

Adapun etnis Dayak yang dirujuk dalam kaitannya dengan permasalahan ini lazimnya adalah berupa perpaduan dari etnis Maanyan, Lawangan, Ngaju, dan dalam beberapa kawasan juga etnis Bukit. Penulis tidak bisa mengeksplorasi lebih jauh tentang hal ini, namun tampaknya ia lebih disebabkan oleh faktor kedekatan domisili saja antar kelompok yang terlibat dalam melting pot itu, bahwa mereka merupakan penduduk yang lebih terdahulu mendiami pesisir teluk raksasa sebelum berkembangnya etnis dan budaya Banjar.

Etnis Dayak Maanyan (Manyan) dahulunya diduga pernah mendiami kawasan yang luas di lembah sungai Negara, dan mereka saat itu tidak bercampur dengan etnis Banjar Batang Banyu yang strukturnya juga masih berupa kantong-kantong pemukiman sepanjang sungai. Belakangan, etnis Maanyan tergeser oleh ledakan

\footnotetext{
${ }^{42}$ Anggraini Antemas, op. cit., h. 15.
} 
pertumbuhan etnis Banjar, sehingga sekarang cuma mendiami daerah Barat Laut Tanah Banjar, yaitu lembah tepi Timur sungai Barito dari Buntok sampai sungai Montalat, dan daerah sebelah Timurnya di sekitar lembah sungai Tabalong dan hulu sungai Balangan. ${ }^{43}$

Helius Sjamsuddin dalam kajiannya tentang pegustian dan tumenggung dalam perlawanan terhadap kolonial Belanda, menggambarkan bahwa etnis Maanyan, utamanya orang Siong dari Paju Apat (di wilayah Kalimantan Tengah seka-rang) sejak sebelum sampai jauh sesudah perang Banjar tampak lebih memihak kepada Belanda, meskipun kalangan elit mereka tetap bertahan dengan kepercayaan asli. ${ }^{44}$

Sungguhpun demikian, terdapat satu kasus unik yang berlangsung sampai periode yang belum lama ini pada kelompok Maanyan di daerah Warukin, bagian utara Kabupaten Tabalong, bahwa mereka masih sering berziarah ke Mesjid (Balai) Banua Lawas yang dianggap sebagai balai perpantangan (gono-gini) antara mereka dengan saudara atau tetangga mereka seetnis yang telah melakukan konversi Islam. ${ }^{45}$ Kendati belum bisa dipastikan apakah kelompok ini termasuk sub etnis Maanyan Patai, yang secara hukum adat dan bahasa dibedakan dari Maanyan Siung, ${ }^{46}$ namun setidak-nya fakta ini memberi makna bahwa rasa memiliki terhadap darah daging sendiri tetap ada dalam budaya etnis Maanyan.

Di samping itu, fakta ini juga menunjukkan bahwa etnis ini berpartisipasi dalam melting pot pembanjaran sangat mungkin terjadi, di mana setelah terpolarisasi secara agama, kelompok Maanyan yang masih bertahan pada religi lama kemudian menyingkir dan membentuk kantong pemukiman baru, sehingga berimplikasi terjadinya pembanjaran pada kelompok yang telah melakukan konversi Islam tadi.

Etnis Dayak kedua yang disebut-sebut sebagai salah satu akar etnis Banjar adalah etnis Lawangan. Etnis ini sekarang mendiami daerah sebelah Utara kota Tanjung berbatasan dengan Kalimantan Tengah dan Kalimantan Timur. $^{47}$ Meskipun belum diketahui secara meyakinkan tentang proses pem-Banjaran kelompok-kelompok Lawangan, namun di dalam konteks perang Banjar, terdapat indikasi kuat bahwa etnis ini menunjukkan sikap yang sebaliknya dari etnis Maanyan, karena seorang pemimpinnya yang Muslim dari sub-etnis Anga, yakni Tumenggung Aryapati, teridentifikasi sebagai sahabatnya Tumenggung Surapati (w 1875 M), seorang kepala Dusun Hulu sebelum pecah perang Banjar yang merupakan keturunan etnis Bakumpai-Siang yang juga sangat mendukung gerakan perlawanan Pangeran Antasari dari Banjar. Bahkan, sebagai kepala Dusun Hilir, Tumenggung Aryapati telah memberikan penghormatan dan bantuan yang sangat baik kepada Pangeran Antasari (w $1862 \mathrm{M}) .{ }^{48}$ Dari sini dapat diduga bahwa secara

\footnotetext{
${ }^{43}$ Alfani Daud., op. cit., h. 33.

${ }^{44}$ Helius Sjamsuddin, op. cit., h. 262-263.

${ }^{45}$ Alfani Daud, loc. cit. dan lihat pula h. 49.

${ }^{46}$ Soerjono Soekanto, Hukum Adat Indonesia, (Jakarta: Raja Grafindo Persada, 2002), Cet. 5,

${ }^{47}$ Alfani Daud, op. cit., h. 34.

${ }^{48}$ Helius Sjamsuddin, loc. cit.
} h. 20 . 
religio-politis, Lawangan turut memiliki andil dalam proses pembentukan etnis Banjar, kendatipun sudah dalam masa-masa yang jauh lebih muda (khususnya di masa-masa akhir perang Banjar, pada paroh akhir abad ke-19 M).

Adapun etnis Ngaju, pada zaman dahulu juga diperkirakan mendiami Tanah Banjar bagian Barat Daya sepanjang aliran sungai Martapura sampai ke Marabahan. Sekarang, etnis ini juga bergerak menjauh dan hanya mendiami daerah aliran sungai Kuala Kapuas, Kapuas Hilir, Kapuas Tengah, Kahayan Hilir, dan Kahayan Tengah di Kalimantan Tengah. Sebagian mereka masih berpegang kepada agama pribumi, sebagian Kristen, dan ada pula yang Islam. Namun demikian, begitu memeluk agama Islam, pada umumnya mereka dianggap telah kehilangan identitasnya sebagai orang Ngaju, sehingga lebih dikenal sebagai "orang Kapuas" saja.

Di sini, perlu pula dikemukakan bahwa secara umum, etnis Bakumpai di sekitar Marabahan, yang menurut Alfani merupakan satu kelompok besar (sub etnis, pen.) dalam etnis Ngaju, memiliki sifat khas yang sangat erat hubungannya dengan etnis Banjar, karena sama-sama telah memiliki identitas agama Islam sejak permulaan abad ke-19 M, kendati proporsi kuantitas keislaman mereka boleh dikatakan tidak sebesar etnis Banjar. ${ }^{49}$ Mereka juga dikenal menggunakan dwi bahasa: bahasa Banjar sebagai bahasa pergaulan dan bahasa Ngaju sebagai bahasa Ibu. Hal ini barangkali erat kaitannya dengan domisili etnis Bakumpai yang hidup saling bertetangga dengan sub etnis Banjar Kuala di sekitar lembah sungai Muara Bahan, sehingga interaksi yang cukup intens antara kedua etnis di kawasan ini pada akhirnya hampir menghilangkan identitas asli dari masingmasing kelompok. ${ }^{50}$

Sementara etnis Bukit, di masa sekarang ini mereka le-bih dikenal dengan sebutan sebagai Dayak Meratus, karena memang pada umumnya mereka mendiami wilayah atas dari pegunungan Meratus yang memanjang dari Utara (daerah Hulu Sungai) ke Selatan (daerah Kabupaten Tapin, Banjar, Tanah Laut, dan Tanah Bumbu).

Dalam konteks asal-muasal etnis Banjar, etnis Bukit harus ditempatkan bersama-sama Banjar sebagai satu rumpun tersendiri yang tampaknya tidak bisa diidentifikasi langsung baik sebagai Melayu ataupun Dayak. Hal ini ditandai oleh lima hal: pertama, etnis Bukit dan Banjar (Pahuluan) dikenal memiliki pola hubungan sosial yang cukup harmonis, yang dibuktikan dengan menyatunya kehidupan kedua etnis pada beberapa daerah. Tradisi Banjar sendiri menunjukkan bahwa orang bukit dikenal sangat suka memanggil orang Banjar yang tidak dikenalnya dengan sebutan dingsanak, yang di dalam kedua bahasa sama-sama berarti saudara. Bahkan, seringkali terjadi proses saling membantu antara orang Banjar dengan orang Bukit.

\footnotetext{
${ }^{49}$ Di antara informan di Kalimantan Tengah, termasuk orang Kapuas (Muslim Ngaju) yang dapat dikonfirmasi tim penulis memiliki pandangan yang bertolak belakang dengan pernyataan itu, karena umumnya antara Ngaju dan Bakumpai merupakan dua etnis yang terpisah dan membentuk pola budaya masing-masing.

${ }^{50}$ Alfani Daud., loc. cit.
} 
Kedua, mitologi Bukit sama sekali tidak merujuk kepada kawasan pegunungan seperti layaknya kelompok-kelompok Dayak, tetapi justru ke kawasan sungai dan lembah yang dikenal merupakan ciri khas kediaman etnis Banjar sejak awal pembentukannya. Hal ini mengindikasikan bahwa dahulunya etnis Bukit lebih merupakan penghuni daerah aliran sungai ketimbang daerah pegunungan.

Ketiga, meskipun banyak kesamaan dalam aspek religi dengan etnis-etnis Dayak lainnya, namun berdasarkan hasil kajian Noerid Haloei Radam, orang Bukit sebenarnya beragama Balian, jadi bukanlah Kaharingan. Nama Kaharingan, yang konon berasal dari danum kaharingan (air kehidupan), muncul sebagai kesalahan identifikasi terhadap religi orang Bukit belaka.

Keempat, etnis Bukit tidak mengenal tradisi mengayau (memotong kepala), satu tradisi yang lazim ditemukan pada banyak kelompok-kelompok Dayak di masa lampau, guna mencari kekuatan gaib (mana) yang dipercaya terdapat dalam bagian-bagian tertentu dari tubuh manusia. ${ }^{51}$

Kelima, bahasa yang dikembangkan etnis Bukit tidaklah jauh berbeda dengan dialek bahasa Banjar hulu, sehingga karenanya sebagian peneliti menempatkan bahasa Bukit lebih sebagai bahasa Banjar yang agak kuno (arkais). Hal ini wajar secara ekologis, karena orang Bukit lebih diikat oleh alam pedalaman yang relatif jauh dari komunikasi dan interaksi dengan luar, sehingga berdampak bagi terbentuknya pola bahasa yang lebih konstan dibandingkan orang Banjar di daerah pesisir yang lebih dapat menerima perubahan dalam tradisi budaya mereka. Namun demikian, hasil observasi belakangan menunjukkan bahwa di pegunungan, nyaris tidak dapat dibedakan dalam pergaulan sehari-hari antara Bukit dengan Banjar, baik dalam hal bahasa maupun penampilan dan ciri-ciri fisik keduanya. Hal ini menopang pola interaksi yang harmonis seperti tergambar dalam proses sosial ekonomi di pasar-pasar tradisional kedua etnis.

Keenam, memang terdapat keunikan tersendiri yang me-nuntut penjelasan multi-perspektif ketika orang Banjar pada umumnya tidak peduli, atau bahkan lebih suka diidentifikasi sebagai Melayu, sementara orang Bukit justru tampak lebih senang disebut sebagai Dayak Meratus. ${ }^{52}$

Berdasarkan uraian di atas, proses terbentuknya etnis Banjar harus dilihat dalam stratum spasio-temporalnya, yang berarti harus ada klasifikasi ruang dan klasifikasi waktu yang berlapis. Dari segi ruang, misalnya, etnis Banjar dapat dikatakan terbentuk pada tiga daerah secara berurutan dengan ciri ekologis dan karakter melting pot masing-masing, yakni daerah Batang Banyu, Pahuluan, dan Kuala. Urutan ruang ini juga sekaligus menggambarkan adanya kronologi waktu pembanjaran.

Sebutan Batang Banyu berarti sungai, dan sering pula berarti nama lain bagi sungai Negara (Bahan) yang bermuara ke sungai Barito. Namun, sebagai suatu daerah ia meliputi wilayah lembah berawa yang cukup luas di sepanjang sungai

${ }^{51}$ Gatut Murniatmo dkk., Khazanah Budaya Lokal: Sebuah Pengan-tar untuk Memahami Kebudayaan Daerah di Nusantara, (Yogyakarta: Adicita Karya Nusa, 2000), h. 133.

${ }^{52}$ Tajuddin Noor ganie, op. cit., h. 1. 
Negara mulai dari sekitar Margasari yang berbatasan dengan daerah Marabahan di sebelah hilir, yang di masa lalu dapat dimasuki dengan mudah dari laut Jawa, terus ke daerah Negara yang sekarang terdiri atas tiga kecamatan (Daha Utara, Daha Selatan, dan Daha Barat) dalam lingkup Kabupaten Hulu Sungai Selatan, dan berujung di daerah Kelua di tepian sungai Tabalong. ${ }^{53}$

Dilihat dari posisi strategis jalur sungainya, dapat diperkirakan bahwa daerah Batang Banyu menjadi sasaran para pendatang tempo dulu yang merasa tidak puas hanya sampai di muara sungai Barito. Seperti dikemukakan di atas bahwa daerah ini diperkirakan pernah menjadi kawasan pemukiman etnis Dayak Maanyan, yang akhirnya terdesak oleh etnis Banjar sendiri. Barangkali, fenomena ini sudah terjadi sejak zaman Kerajaan Nan Sarunai, sebelum berdirinya Kerajaan Negara Dipa, yang banyak diceritakan di dalam mitologi Maanyan. ${ }^{54} \mathrm{Nah}$, jika dihubungkan dengan kasus di Banua Lawas di atas, jelas memungkinkan sekali bagi berlangsungnya asimilasi lengkap antara etnis Maanyan dengan para pendatang di daerah ini, sehingga sebagai outputnya, lahirlah generasi baru yang disebut orang Banjar Batang Banyu.

Sementara itu, istilah pahuluan merujuk kepada tempat yang berada di bagian hulu atau sering disebut daerah hulu sungai. Sebagai suatu daerah, Pahuluan meliputi daerah aliran sungai-sungai anak cabang sungai Negara yang semuanya berhulu di pegunungan Meratus, dan yang terpenting di antaranya adalah sungai Tabalung, Balangan, (Batang) Alai, Labuhan Amas, Amandit, dan Tapin. Semua sungai ini, sam-pai batas-batas tertentu memiliki arus yang relatif tidak deras; malah di antaranya ada yang masih dipengaruhi oleh pasang surutnya air laut hingga saat ini, sehingga juga relatif mudah dimudiki dari laut Jawa, melalui teluk raksasa yang dikenal pada zaman dahulu. ${ }^{55}$ Hal ini juga berarti bahwa daerah Pahuluan termasuk potensial bagi melting pot kebudayaan. Seperti disebutkan di atas, etnis Dayak Lawangan, dan mungkin pula etnis Bukit, dahulunya menempati daerah Pahuluan itu sebelum akhirnya mereka juga terdesak lebih ke pegunungan bagian atas. Percampuran budaya antara kedua etnis ini dengan para pendatang akhirnya melahirkan generasi baru yang disebut orang Banjar Pahuluan.

Adapun istilah Kuala, sebenarnya lebih merujuk kepada dialek bahasa Banjar yang dikembangkan oleh penduduk daerah kota Banjarmasin, Martapura, Marabahan dan sekitarnya, yang mengingatkan pula kepada istilah dalam bahasa Melayu untuk menunjukkan muara sungai, yang kemudian melekat sebagai nama daerah, seperti Kuala Lumpur dan Kuala Trengganu di Semenanjung Malaya, Kuala Tungkal dan Kuala Elok di Sumatera, serta Kuala Pembuang dan Kuala Kapuas di Kalimantan. Orang Banjar Kuala sendiri lazimnya dalam tradisi hanya disebut sebagai orang Banjar, karena memang munculnya sebutan Banjar sendiri adalah di dalam konteks keberadaan mereka.

Sebagai daerah muara, sudah pasti penduduknya memiliki pola kebudayaan yang lebih terbuka dan dinamis dibandingkan penduduk hulu dan pedalaman

\footnotetext{
${ }^{53}$ Alfani Daud, op. cit., h. 1.

${ }^{54}$ Tajuddin Noor Ganie, op. cit., h. 14.

${ }^{55}$ Alfani Daud, loc. cit. Lihat juga h. 38.
} 
Kalimantan. Ini berimplikasi kepada besarnya kemungkinan terbentuknya etnis Banjar sebagai perpaduan para pendatang, yang umumnya berprofesi sebagai pedagang, dengan penduduk pribumi. Akan tetapi, tampaknya tidak ada penduduk yang bisa di-sebut sebagai pribumi sempurna di daerah ini, yang mungkin karena posisinya yang termasuk daerah transit perdagangan internasional. Kebanyakan penduduknya justru terbukti berasal dari Banjar Pahuluan dan Batang Banyu sendiri yang kebetulan sudah sekian lama menetap di sana. Bahkan, menurut Alfani, etnis Dayak Ngaju (Biaju) yang terlebih dahulu mendiami daerah ini pun tidak bisa dikatakan pribumi. ${ }^{56}$ Namun bagaimanapun, asimilasi yang terjadi di daerah ini bisa dikategorisasi sebagai gelombang terakhir dalam proses asimilasi lengkap yang membentuk etnis Banjar, karena terdapatnya unsur Pahuluan dan Batang Banyu dimaksud.

\section{Organisasi Sosial}

Dari uraian di atas, tampak bahwa terbentuknya ketiga sub etnis Banjar sudah merupakan proses primordial yang lambat laun berkonvergensi kepada kesatuan sosio-kultural Banjar. Artinya, dapat saja dibenarkan bahwa proses pembanjaran berlangsung dari hilir (Kuala) ke daerah hulu Tanah Banjar, ${ }^{57}$ namun harus dalam catatan bahwa proses itu merupakan tahap akhir pembentukan, yang ditandai dengan mulai adanya identifikasi dan kesadaran kultural kolektif sebagai "orang Banjar" secara lebih merata pada masyarakat di ketiga daerah tersebut, walaupun secara genetik mereka mewakili garis yang berbeda-beda. ${ }^{58}$

Sebelum tahapan ini, proto atau cikal-bakal etnis Banjar sudah terbentuk di wilayah yang luas sekitar hulu sungai Tabalong sebelum berdirinya kerajaan Negara Dipa, yang diduga kuat merupakan perpaduan dari etnis Melayu (Baca: Deutro Melayu, Pen.), Maanyan, Lawangan, dan juga Bukit. Kemudian, proto Banjar yang masih terserak di pusat-pusat pemukiman pada masing-masing anak cabang sungai Tabalong dan Negara itu disatukan secara sosial dan politik oleh Kerajaan Tanjung Pura yang konon berbudaya Budha-Sriwijaya, dan selanjutnya oleh Kerajaan Negara Dipa yang berbudaya Hindu-Jawa.

Fenomena ini terus berlangsung ketika Kerajaan Negara Daha berdiri sepeninggal Patih Lambung Mangkurat, dan kemudian menggantikan kekuasaan Negara Dipa pada abad ke-15 M. Pada saat itu, Tanah Banjar sudah didiami oleh para pendatang Arab, Melayu, dan Bugis yang turut terlibat dalam melting pot. Akhirnya, proses ini disudahi dengan gerakan kultural yang lebih ke hilir seiring terbentuk dan berkembangnya Kerajaan Banjar pada abad ke-16 M yang

\footnotetext{
${ }^{56} I$ Ibid., h. 34. Sebenarnya ia sempat mengidentifikasi secara sekilas satu kelompok masyarakat yang mengembangkan bahasa sendiri di sekitar lembah sungai Barito, namun tidak berhasil mengeksplorasi asal-usulnya. Ibid., h. 46.

${ }^{57}$ Syarrifuddin R. et.al., Pembinaan Budaya dalam Lingkungan Kelu-arga Daerah Kalimantan Selatan, (Banjarmasin: Bagian Proyek Peng-kajian dan Pembinaan Nilai-Nilai Budaya Depdikbud Kalsel, 1995), h. 10.

${ }^{58}$ Dalam skala pergaulan di wilayah tradisonal Banjar sendiri, lazimnya sebutan Banjar hanya dikenakan bagi orang yang tinggal di daerah Banjar Kuala, karena orang Batang Banyu dan Pahuluan menyebut orang yang tinggal di daerah Kuala itu sebagai urang Banjar. Namun, dalam skala yang lebih luas, ketika berada di wilayah Tanah Banjar, semua orang di ketiga daerah Banjar itu mengidentifikasi dirinya sebagai urang Banjar.
} 
kemudian menjadikan Islam sebagai identitas utama bagi masyarakat dan kebudayaan Banjar.

Asal-usul istilah Banjar sendiri, yang meskipun sudah dikenal selama berabad-abad silam, ${ }^{59}$ sebenarnya memiliki beberapa versi. Versi pertama ${ }^{60}$ menyebutkan bahwa kata Banjar berasal dari kata Banjarmasih, sebuah kampung di muara sungai kuyin (kuin), anak sungai Barito yang terletak di antara pulau Kembang dengan pulau Alalak. Dinamakan Banjarmasih sebab daerah Banjar ini diperintah oleh Patih Masih.

Nama dan identitas patih ini tidak diketahui secara jelas. Arthum Artha menyebutnya sebagai versi Banjar belaka dari namanya yang menggunakan bahasa Jawa, Patih Minasih, yang konon bersama-sama Sultan Demak, Raden Arya Trenggono, bertualang ke daerah pantai selatan Tanjung Pura. Jadi, Patih Masih dengan Patih Minasih adalah nama berbeda dari orang yang sama, seperti pula Raden Arya Trenggono yang setelah ke Kalimantan menggunakan nama Patih Arya Trenggana. Menurut sumber lain, kata ini justru berasal dari bahasa Oloh Ngaju yang memberikan sebutan untuk orang Melayu yang tinggal bertetangga dengan mereka dengan istilah Oloh Masi. Oleh karenanya, Patih Masih tidak lain daripada sebutan bagi patih yang memerintah orang-orang melayu, sehingga dapat disimpulkan bahwa Banjarmasih merupakan kampung Oloh Masi atau kampung Melayu yang terletak di antara kantong-kantong perkampungan Oloh Ngaju yang menggunakan bahasa lokal Brangas di sekitar muara sungai Kuyin tersebut.

Selanjutnya, kata Banjarmasih ini lambat laun berubah menjadi Banjarmasin. Perubahan-perubahan yang bersifat mekanis ini tampaknya diakibatkan oleh catatan resmi dari Pemerintah Hindia Belanda. M. Edwar Saleh, ${ }^{61}$ misalnya, merujuk kepada surat-surat di tahun 1664 M, di mana nama Banjarmasih saat itu masih digunakan, seperti kata-kata: "Pangeran Suryanata in Banjarmasch (masih)....", "Pangeran Ratu in Banjarmasch (masih)...", :Prince in Banjarmasch". Selanjutnya, masih berdasarkan data yang dihimpunnya, pada tahun $1733 \mathrm{M}$ kampung ini sudah berubah menjadi Bandjermasing dan menjadi Bandjermasin di tahun 1845 .

Seiring perkembangan zaman, istilah Banjar yang tam-pak merupakan pengucapan ringkas dari "Banjarmasin", tidaklah lagi menjadi nama kampung sebagaimana disebutkan di atas, tetapi lambat laun meluas menjadi sebutan untuk menyatakan identitas kultural suatu negeri, baik dalam hal bahasa, kerajaan, etnis, orang, dan sebagainya, sehingga kemudian dikenal istilah-istilah seperti orang Banjar, suku Banjar, bahasa Banjar, Kerajaan Banjar, dan banua Banjar.

Adapun versi kedua, ${ }^{62}$ menyebutkan bahwa istilah Banjar mengingatkan pada banyaknya pepohonan yang tumbuh berbanjar-banjar di tepian sungai Martapura.

${ }^{59}$ Abdurrahman, op. cit., h. 13.

${ }^{60}$ M. Edwar Saleh, Sekilas Mengenai Daerah Banjar dan Kebudaya-an Sungainya Sampai Dengan Akhir Abad ke-19, (Banjarmasin: Proyek Pengembangan Permuseuman Kalimantan Selatan Depdikbud., 1983/ 1984), h. 10.

${ }^{61}$ Ibid.

${ }^{62}$ Arthum Artha, op. cit. h. 13-14. 
Di samping itu, air sungai Martapura yang dipengaruhi oleh pasang-surut air laut Jawa terkadang menimbulkan rasa asin, sehingga juga mendekatkan penyebutan Banjar masin. Namun, sebagai se-buah nama, konsep Banjarmasin baru muncul dalam silsilah kerajaan Banjar setelah pudarnya kerajaan Negara Daha.

Sungguhpun versi pertama tampak lebih dapat diterima dalam optik sosiokultural, namun kita tetap mengadopsi versi kedua itu sebagai ikon komplementer. Oleh karenanya, dapat ditarik benang merah bahwa istilah Banjar muncul tatkala Islam mulai menjadi identitas religius masyarakat di daerah ini. Dengan kata lain, Banjar sebagai sebuah kultur bukanlah entitas yang telah mengada sejak ribuan tahun lalu seiring terbentuknya kelompok-kelompok masyarakat purba, tetapi ia adalah identitas kultural baru, yang mengada seiring merambahnya dakwah agama Islam pada abad ke-15 M. ${ }^{63}$

Adapun tentang penyebaran etnis Banjar, yang perlu disebutkan dalam konteks kajian ini hanyalah sekitar berlangsungnya proses pembanjaran yang seperti disebutkan di atas dimulai dari kawasan hilir (kuala) ke hulu. Proses ini sekaligus bermakna agamis dan politis, sebab dalam banyak kasus di kemudian hari, seseorang bisa disebut orang Banjar ketika ia melakukan konversi Islam atau menerima dan mendukung penuh kesultanan Banjar.

Sehubungan dengan itu, Ahmad Basuni menulis bahwa sebelum Sultan Suriansyah naik tahta sudah teridentifikasi beberapa daerah yang tunduk ke bawah pengaruh Banjarmasin, seperti Sambas, Batang Lawi, Sukadana, Kotawaringin, Pembuang, Sampit, Mendawai, dan Sebangau. Para utusan dari daerah-daerah ini pada musim Barat datang ke Banjarmasin mengantarkan upeti, dan pada musim Timur kembali ke daerahnya masing-masing.

Disebutkan pula pembesar yang mengurusi daerah-daerah itu adalah seorang patih yang dikenal dengan nama Patih Aria Tranggana. ${ }^{64}$ Menurut Yusuf Halidi, Patih ini adalah penguasa kota Muara Bahan pada awal abad ke-15 M, yang posisinya semakin terhormat ketika berdirinya Kerajaan Negara Daha, lantaran bandar pelabuhan yang sejak zaman Negara Dipa berada di Pebaungan (Margasari) dipindahkan ke Muara Bahan (Marabahan), seiring bergantinya kekuasaan Putri Kalungsu yang dijalankan oleh Lambung Mangkurat sebagai Mangkubumi kepada Pangeran Sekar Sungsang (Maharaja Sari Kaburangan) ${ }^{65}$

Jika hal itu benar secara historis, tentu dapat dipastikan bahwa proses pembanjaran selanjutnya akan membawa implikasi yang kompleks dalam tata kehidupan masyarakat Kalimantan. Sebab, penyebaran etnis ini, terutama di luar Tanah Banjar, akan berhadapan dengan sejumlah fenomena yang di antaranya cukup jauh berbeda dari yang ditemukan pada pola hubungan antara Banjar pada satu pihak dengan etnis Bukit, Maanyan, Lawangan, dan Ngaju di pihak lain. Sebagai satu indikasi, data hasil pencatatan penduduk tahun 1930 M menunjukkan bahwa etnis Banjar telah cukup tersebar di pulau Kalimantan. Bahkan untuk

\footnotetext{
${ }^{63}$ Ahmad Basuni, Nur Islam di Kalimantan Selatan (Sejarah Masuk-nya Islam di Kalimantan), (Surabaya: Bina Ilmu, 1986), Cet. 1, h. 63.

${ }^{64}$ Ibid., h. 38.

65 Yusuf Halidi, Ulama Besar Kalimantan: Syekh Muhammad Arsyad Al Banjari, (Banjarmasin: Aulia, 1980), cet. IV, h. 23.
} 
daerah Pulau Laut, Tanah Bumbu, Samarinda, dan Kuala Kapuas, mencapai kisaran seperdua $(50 \%)$ atau bahkan lebih dari total jumlah penduduk masingmasing. ${ }^{66}$ Hal ini menandakan bahwa etnis Banjar telah mengalami perkembangan yang sedemikian rupa, baik dilihat dari segi geografi, genetika, budaya, politik, maupun religi.

\section{Penutup}

Atas dasar pembahasan di atas, penulis sampai pada sebuah kesimpulan bahwa secara sosiohistoris masyarakat Banjar adalah kelompok sosial heterogen yang terkonfigurasi dari berbagai suku-bangsa dan ras yang selama ratusan tahun telah menjalin kehidupan bersama, sehingga kemudian membentuk identitas etnis Banjar. Kelompok sosial heterogen itu memang terbentuk melalui proses yang tidak sepenuhnya alami (primordial), tetapi juga dipengaruhi oleh faktor-faktor lain yang cukup kompleks.

Implikasinya adalah bahwa asal-usul dan identitas urang Banjar tidak bisa dirumuskan secara parsial dengan menekankan pada pendekatan-pendekatan tertentu saja. Apalagi fenomena ini berlangsung sampai paroh pertama abad ke-20 $M$ di saat mana konsep identitas etnis mulai menyeruak ke permukaan, sehingga turut mempengaruhi pendekatan-pendekatan dalam penelitian etnografi kala itu.

Dengan demikian, tulisan ini tidaklah dimaksudkan untuk memihak salah satu pendekatan yang terkesan saling dikotomis tentang asal-usul dan identitas Banjar tersebut. Sebab, pendekatan-pendekatan itu hanyalah alat untuk memahami sebuah konstruks realitas - dalam hal ini adalah Banjar - yang tidak sepenuhnya riil, sehingga masing-masing tentu memiliki kelebihan dan kekurangan yang seyogyanya justru saling menutupi dan melengkapi.

\section{DAFTAR PUSTAKA}

Abdurrahman, Beberapa Catatan tentang Undang-Undang Sultan Adam Ditinjau dari Persfektif Sejarah Hukum, Hukum Islam, dan Hukum Adat Banjar, Banjarmasin, Fakultas Hukum UNLAM, 1984.

Artha, Arthum, Dari Bandarmasih ke Banjarmasin, Banjarmasin, Pustaka Artha Mardaheka.

Basuni, Ahmad, Nur Islam di Kalimantan Selatan (Sejarah Masuknya Islam di Kalimantan), Surabaya, Bina Ilmu, 1986.

Buletin Wacana Postra, Edisi 062002

Daud, Alfani, Islam dan Masyarakat Banjar: Diskripsi dan Analisas Kebudayaan Banjar, Jakarta, Raja Grafindo Persada, 1997.

${ }^{66}$ Alfani Daud, op. cit., h. 41. 
Jurnal Gerbang, Nomor 13, Vol. V, Oktober 2002-Januari 2003

Jurnal Kebudayaan Kandil, Edisi 6, Tahun II, Agustus-Oktober 2004

Halidi, Yusuf, Ulama Besar Kalimantan: Syekh Muhammad Arsyad Al Banjari, Banjarmasin: Aulia, 1980.

Ham, Ong Hok, "Masalah Cina di Indonesia Ditinjau dari Sejarah Indonesia" dalam Yahya Theo (ed.), Sekitar Pembauran Bangsa di Indo-nesia, Jakarta, Yayasan Kesejahteraan Keluarga Pemuda "66", 1985.

Hollander, J. J. de, Handlelding bij de beofening der Maleische Taalen, diterjemahkan oleh T. W. Kamil dengan judul Pedoman Bahasa dan Sastra Melayu, Jakarta, Balai Pustaka, 1984.

http://www.stevegaspersz.wordpress.com/2007/12/07/islam_kristen_dalam_diskur sus_kebudayaan_dan_etnisitas

http://www.britannica.com/ethnic

http://www.merriam-webster.com/dictionary/ethnic

Meier, Fritz, "Metode-Metode Pendekatan", dalam Gustave E. von Grunebaum (ed.), Unity and Variety in Muslim Civilization, diterjemahkan ke dalam bahasa Indonesia oleh Effendi N. Yahya dengan judul, Islam: Kesatuan dalam Keragaman, Jakarta,Yayasan Obor, 1975

Murniatmo, Gatut dkk., Khazanah Budaya Lokal: Sebuah Pengantar untuk Memahami Kebudayaan Daerah di Nusantara, Yogyakarta, Adicita Karya Nusa, 2000.

Poesponegoro, Marwati Djoened dan Nugroho Notosusanto, Sejarah Nasional Indonesia II, Jakarta, Balai Pustaka, 1993.

Rahardjo, M. Dawam, "Ilmu Sejarah Profetik dan Analisis Transformasi Masyarakat", Pengantar dalam Kuntowijoyo, Paradigma Islam, Bandung, Mizan.

Rass, J.J., Hikajat Bandjar: A Study in Malay Historiography, diterjemahkan ke dalam bahasa Melayu oleh Siti Hawa Saleh dengan judul Hikayat Banjar, Kuala Lumpur, Dewan Bahasa Kementerian Pendidikan, 1991

Saleh, M. Idwar, Sejarah Daerah Kalimantan Selatan, Jakarta, Proyek Inventarisasi dan Dokumentasi Kebudayaan Daerah, 1978.

-------, Sekilas Mengenai Daerah Banjar dan Kebudayaan Sungainya Sampai Dengan Akhir Abad ke-19, Banjarmasin, Proyek Pengembangan Permuseuman Kalimantan Selatan Depdikbud., 1983/ 1984.

Samad, Duski, Syekh Burhanuddin dan Islamisasi Minangkabau, Jakarta, The Minangkabau Foundation, 2003.

Sedyawati, Edi, Budaya Indonesia Kajian Arkeologi, Seni, dan Sejarah, Jakarta, Raja Grafindo Persada, 2001 
Soekanto, Soerjono, Hukum Adat Indonesia, Jakarta, Raja Grafindo Persada, 2002.

Syarifuddin R. et.al., Pembinaan Budaya dalam Lingkungan Kelu-arga Daerah Kalimantan Selatan, Banjarmasin, Bagian Proyek Peng-kajian dan Pembinaan Nilai-Nilai Budaya Depdikbud Kalsel, 1995.

Tim Penyusun Kamus, Kamus Besar Bahasa Indonesia, Jakarta, Balai Pustaka, 1990. 